\title{
Navigation of Innovative Management in the Local Spheres of Government in South Africa - An Issue for Consideration
}

\author{
KKL Pilusa \\ Ba-Phalaborwa Municipality \\ ML Shipalana \\ Department of Health
}

\begin{abstract}
It is a global concern that most local spheres of government are usually faced with a major challenge of meeting the basic needs of citizens, particularly in the developing countries such as South Africa, where majority of people depending entirely on public services. It is observed that the local spheres of government are unable to carry out their constitutional mandate to provide public goods and services such as education, housing health, water and sanitation. This situation, among others, is mainly exacerbated by ineffective innovative management practices. This article sought to navigate innovative management practices in the local spheres of government in South Africa and suggests strategies that can be applied for service delivery improvement. The article used conceptual framework to analyse innovative management practices in the context of the local spheres of government. In the process, literature has revealed that most of local spheres of government are mainly characterised with ineffective innovative management practices. These management practices include, strategic planning, operational plans and performance management systems. It is evident that the current state of affairs, drastically affects service delivery improvement. This article suggests collaborative approach as mechanism to enhance service delivery in the local spheres of government.
\end{abstract}

\section{INTRODUCTION}

Local spheres of government are at the utility distribution coalface of service delivery. In this regard, government officials are expected to be the drivers for the provision of public goods and services to meet the basic needs of the citizens, but little knowledge exists about their capacity to do so. The ability of local authorities to innovate and the instrument used to determine the maturity of innovations. It is important to note that inadequate delivery of services has triggered protests in numerous municipalities throughout South Africa. In certain cases, the solution to these problems can be considering the use of innovations, like implementing new or updated methods and technology to enhance the operations of a local municipality. However, only if the capacity of the local officials to introduce and handle these developments is improved can achieve effective innovation in service delivery. It is worth noting that it is important to establish the existing strengths and shortcomings of the innovation capacities of the municipalities as a starting point. Appropriate measuring instruments are needed to obtain accurate, timely and relevant information about innovation capabilities.

\section{LITERATURE REVIEW}

Importantly, based on Section 57(6) of the Local Government: Municipal Systems Act, 2000, a contract of employment for a municipal manager is provi ded for or a fixed term of employment of up to a maximum of five years, for the manager reporting to the municipal manager must not exceed a period ending one year after the election of the next municipal council. The output arrangement should be achieved within a reasonable period of time after the appointment of an individual as the accounting officer or as a senior manager who is personally answerable to the municipal manager and then within one month from the start of the municipal financial year. The job contract needs to be in effect to provide specifics of the responsibilities, reimbursement, incentives as well as other work contract terms and the output arrangement, subject to applicable labour legislation.

Therefore, the wind of change towards innovations in respect of market and political pluralism that took place across globally, and the collapse of communism, have sent important message to most developing countries that they should also view innovative management approaches and strategies not only from a private sector perspective, but also in the public sector as an important aspect. Larbi (1999:11) in Shipalana (2019) postulates that the United States and Britain have an influence on the effects of innovations had not gone unnoticed in other countries. However, Hess and Adams (2007:1) in Shipalana (2019) note that the public sector is primarily facing the obstacle of adopting innovative approaches to management as a new method to service delivery improvement.

\section{$>$ Requirement for creative management practices}

Given the rapid change and changing management skills and the degradation of public sector ethical behaviour, people are demanding professional services that will meet their standards. It is believed that innovation can help to find new ways of reaching citizens and ensuring maximum value for service. Key to understanding why public sector innovation is an effective initiative is to return 
and examine how it differs from prior activities directed at rediscovering public services (Demir and Yavuz, 2009).

However, the benefits of the emergence of creative management, based on Bernie, Hafsi and Deschamps (2011:1), are that it could spur debates on future developments in the public service. Hess and Adams (2007:4) further suggest that the ideas and practice of creative management methods and techniques in developing countries during their predominance is considered to have generated improved performance and productivity. Conversely, many discourses have been removed from areas such as policy and management, which necessitates ongoing academic work on creative management methods and public service strategies.

Borins (2002:467) in Shipalana (2019) states that creative administration has been a topic of tremendous public interest and private sector managers. Thus, Bloch, Bugge and Sliperseater (2010) note that both state-owned and private enterprises provide public services with Borins (2002:467) agreeing that rapid technological growth in the private sector has created incentives for businesses to introduce new products, change their manufacturing processes and conduct business in new ways. Innovation wasn't seen as a prerogative for the public sector. Hartly (2005:27) agrees with Borins (2002) in this statement, adding that private-sector innovation requires implicit information, less well-defined processes are traceable to cost-benefit analysis, and are quantified more highly subjective than the overwhelmingly sustainability-oriented public services.

Arslan (2009) argues that the Turkish municipal authorities had handled economic growth policies and legal planning effectively by responding to rapid changes in their climate and the dynamics of their governance. Government attempts to turn themselves into even more organizations geared to the results and the introduction of performance assessment mechanisms and administration philosophy that are the key component of the New Public Management (NPM) theory, helping policymakers and elected authorities in their decision-making, openness and outcomeorientedness (Torres et al., 2006). Conversely, it indicates management style and environment affecting attitudes towards acceptance of innovation (Aarons, 2004; Frambach and Schillewaert, 2002). This may also promote and inspire the implementation of other programs such as egovernment, until the company is engaged in strategic innovation ventures and these produce positive results. It is concluded that in time, witnessing the revolutionary management methods, resulting revolutionary culture and organizational environment would positively impact other managerial developments. This will eventually assess its effects on economic and civic development at local level (Martin, 2000).

Progressively, scholars have not provided comprehensive attention to the idea of creative public service management in developing countries such as South Africa; therefore, they focus on studies mainly carried out in developed countries in the private sectors. Canningham and Karakasidou (2009:1) in Shipalana (2019) enable this notion by suggesting that the idea and philosophy of creative management has been established mainly in developing countries from around private sector with a historical emphasis on product growth. Sørensen and Torfing (2012:1) approve by indicating that it is public knowledge that creative administration was originally regarded as the secret to private sector performance in developing countries. However, Mayer (2012:5) argues that development of creative public sector management is required to enhance service delivery.

\section{The process of muddling through creative management}

Taking strategic decisions in the real world is generally not about making logical, measured choices (March 2005); rather, strategy and strategic management requires a variety of other things, such as rewarding, observing law, organizational slack and other non-rational elements. One of the counterpoints to the logical model of decision-making - where decision-makers define desires, challenges, solutions, and make choices to optimize utility with perfect knowledge is the narrow tradition of rationality, where decision-makers make choices within the restricted rationality context. Without the knowledge, power or cognitive capacity to make a full judgment of the above-mentioned factors, decision-makers consider their reason bound. This paradigm runs counter to some of the concepts of neoclassical economics but has become popular in many disciplines, including strategic management.

Incrementalism is one of the traditions in the finite line of reason, better known as muddling through. Lindblom formulated it in two main papers (Lindblom 1959, 1979), and it has influenced the literature of management in many respects. Incrementalism of Lindblom is a viewpoint which in essence is both behavioural and evolutionary and promotes a fluid view of the world. Decision makers don't transform the world around. Instead, they do so in ways while defining solutions that are unlikely to fundamentally change the status quo. Lindblom describes this method in his 1959 article as 'successive narrow comparisons' (Lindblom 1959: 81), although he describes it as 'plain incremental analysis' or 'disjoined incrementalism' in his later work (Lindblom 1979: 517).

Lindblom 's insight was influential in science literature on management and organization. In their article reviewing the organizational learning literature, Levitt and March describe Lindblom's perspective as one of the 'three classical insights taken from organizational behavioural research' (Levitt and March 1988: 320). March considers Lindblom in scholars in the school of 'broad rationality' where 'individuals and groups simplify a decision problem due to the difficulty of anticipating or considering all alternatives and all knowledge' (March 1978: 591). In their seminal work on the company, Amit and Schoemaker (1993) refer to Lindblom 's theory as a package of tools and skills, as do Daft and Weick (1984) in their analysis of organizations as representation structures. 
However, there is a question over how incrementalism actually reflects the decision-making cycle, not to mention whether or not it is superior to other forms of decisionmaking. Nevertheless, Eisenhardt 's analysis of rapid strategic decisions in high-velocity environments (1989) fails to provide support for the argument that decisions consume a great deal of time. Eisenhardt argues that while people may be boundedly moral, they are also 'capable of engaging in sensible problem-solving techniques to help overcome their weaknesses' (Eisenhardt 1989: 573)

In the literature on strategic management, incrementalism has taken charge in thinking about making a plan and handling structural change. Johnson (1988) defines incrementalism as 'a descriptor of strategic processes of management' that 'went into being in the $1980 \mathrm{~s}$ and took on normative consequences' (Johnson 1988: 75). Fahey (1981) lumps incrementalism with 'a less populated but nevertheless significant literary body. On the roles of behavioural and political influences in organizational strategy growth "(Fahey 1981: 43). Yet Eisenhardt and Zbaracki (1992) note that since 2010, even if confined to Scholar 's quest for the sentence, 16,800 published items have been found.

\section{> Strategic planning as innovative practical management}

The capacity of a local government to effectively prepare and achieve its priorities is used as a basis for furthering the involvement of a community in strategic management by connecting planning with assessment, budgeting, and accountability processes. The consequence is a society that thinks and acts strategically to achieve its desired goals in the long term. Arslan (2009) claims that for more than four years now, strategic management has been used by the Turkish local authorities, but little is known about how it is implemented and the results achieved. Authorities have the option to force initiative through enforcement policy that, through government rules or regulations, be it prosecute or reward certain behaviors (Holden, 2006). Although governments have the power to implement such regulatory action, for the Turkish background, there seems to be no sign of that. Maybe, as Vinzant and Vinzant (1996) put it; strategic management may be "exceedingly" challenging to some local authorities with regard to the widely publicized allocation of resources, lack of autonomy, and critical political landscape.

However, Arpaci and Arifoglu (2009) argue that in some part of the value chain of an organization, the occurrence of a successful innovation associated with a product, service or process should be accompanied by a corporate need, which in turn is enforced with professionalism and skill through innovation activities. To maintain an organization's effective innovation management, a sound creative strategic approach needs to be created. Some researchers including Lihua and Zheng (2005) find evidence of the impact of transformational leaderships and strategic planning on the performance of applications for e-government. They argue further that changes in organization have costs, benefits and risks. The strategic planning will therefore be helpful in preparing the government organizations to deal with all sorts of uncertainties. Therefore, a need for a systematic approach to public sector innovation would result in positive outcomes.

Consequently, not only e-government and Total Quality Management (TQM) follow some similar goals from a theoretical perspective, but they also share an significant collection of core concepts and values (Moura, ESP, 2009). In particular, customer focus, process management and involvement of people are key elements which indicate a connection between the two approaches listed above. Alternatively, the core concepts also commonly shared by all are the objectives of which managerial innovation practices assert such as accountability, transparency, efficiency, effectiveness and responsiveness (Arslan, 2011). The dissemination of managerial technologies and outreach is a result of cumulative e-government activity over time by local governments. The pre-existing innovation potential of a local government results in institutional capacity building, which in effect promotes greater flexibility in the continuous digitalization of government (Arslan, 2011).

\section{$>$ Performance measurement as innovative practice in management}

Measuring performance and managing performance are different concepts which often confuse practitioners. Performance management is what you do with the performance measurement information that you've developed. Managing efficiency involves using knowledge from performance assessments to monitor the public resources and processes (Lichiello, 1999: 13). DeGroot (2005) stresses the importance of stepping up performance efforts in local public services. Performance management is the key to assisting local leadership in implementing the vision and ensuring resource delivery is productive and successful. In addition, local authorities are insistently embracing performance management to deliver effective services to local residents, focus on the resources that matter most, and are able to recognise problems and find solutions (DeGroot, 2005:3). Since the decision-making process remains a complex collection of sub-systems that may conflict with citizens 'expectations, political requirements, fiscal restrictions, decisions taken in previous years, and public administrators' professional standards (Rivenbark and Kelly, 2003). Inversely, once successfully applied and sustained, performance management systems have the potential to transform governments because of their capacity to improve performance and effectiveness (Padovani et. al., 2009).

Although several drivers influence decision-making in management, particularly in complex environments (Powers, 2009), measuring performance data is most often expected to act as a key source for informing the improvement efforts of many managerial functions. Inclusive, such as strategic management process, organizational planning and management, stakeholder relations, budgeting, human resources management, appraisal, and so on (Powers, 2009: 2). Monitoring and 
enhancing the quality of government services is the key factor here (Kwon, 2006).

Operationalising innovation management in
government spheres
Svara (2008) points out the value of innovation in government, and argues that the forms, degree, and effect of government innovation and the organizational characteristics associated with innovation variability are minimal, especially from a scholarly perspective. He described "innovation" as "the introduction, by reference to Damanpour and Evans (1984), of new or alternating existing practices with the intention of producing positive results in (Svara, 2008: 2). Both forms of innovation are (a) adoption of "standard" or "leading" new approaches from outside the organization, such as e-government services, and (b) invention of new approaches or substantial modification of other organizations' methods or practices to create new approaches, that is, "reinvention" (Svara, 2008: 2).

Further debates, however, continue on technical progress in public entities that are referred to as maturation models, and that these models appear to dominate professional debates and academic work (Hiller and Bélanger 2001; Layne and Lee 2001; UN and ASPA 2002 as cited in Svara 2008). The cognitive and social paradigm fits well with the concept of incrementalism, implying that policy progress appears to take place over extended periods in gradual steps (Brown, 2007). That is, any successful experience with an innovative management practice can lead to a new one being adopted. Alternatively, the idea of blurriness and dimensionality of types of innovation in the public sector is set out in reference to Moore and Hartley (2008), Walker et al. (2010). Innovations should be implemented concurrently, rather than adopting a linear pathway. That is; one innovation may depend on another for successful adoption (Walker et al., 2010: 14). A positive relationship between management innovations and performance management has therefore been detected in Briton local governments. Also there is evidence of the positive relationship between the environment of organizational innovation and private sector use of information technology innovation (Min, 2009).

Also several studies show that schooling is a backdrop to creativity. That is; innovation means that new ideas, processes or products are generated and implemented (Chen et al., 2009). Meanwhile, the government reform literature acknowledges a need for strong top management commitment to performance measurement. Cavalluzzo and Ittner (2004: 247) maintain that while administrative and technological factors are expected to affect performance measurement execution, their effect is secondary to that of organizational factors. They contend that top management support is critical to successful implementation because these managers can focus resources, goals and strategies on initiatives that they consider worthwhile and deny resources to initiatives that they do not support, as well as provide the necessary political assistance to motivate or push individuals who resist the initiative aside.

\section{> Steering local government innovation measures}

The Municipal Systems Act (section 46) necessitates the management to respond to the needs of the community; to promote a cultural values of public service and personal responsibility among its staff; to carry out its functions through operationally efficient and administrative units; to assign clear management responsibilities to the governmental departments and techniques; delegating tasks to the most appropriate administrative level; and establishing a performance management system (RSA 2000:32). Therefore, the role of managers is to recognize and organize public policy, and to interpret operational services policy directives. This task is essentially to give effect to the policy-makers' decisions.

Importantly, departments and divisions typically perform the administrative tasks of municipalities, and the roles are delegated to certain departments and divisions on the basis of specialization. Therefore, the health and engineering functions are assigned to the health department and the engineering department respectively (Du Toit, Knipe, Van Niekerk, Van der Waldt, \& Doyle 2002:79). The exercises or operations that the administrative executive institutions carry out are known collectively as municipal government.

Notably, a person chosen as a municipal manager should have the appropriate knowledge and skills to carry out the duties related to the post as provided for in section 82(2) of the Municipal Structures Act (RSA 1998:33). While section 56 of the Municipal Systems Act (RSA, 2000:52) appoints the municipal managers to account. Section 51(i) of the Municipal Structures Act therefore allows the municipality to structure its administration in such a way that it can keep the municipal manager responsible for the municipality's overall results (RSA 2000:34). This would have two consequences: -the council must have the means to ask the municipal manager for clarification and to assess his / her results; and-the municipal manager must have the resources to control the administration so that he / she can account for the performance of the entire management. Comparably, all managers of various departments who are accountable to the municipal manager are required to account to the accounting officer.

Section 55(1) of the Municipal Systems Act provides that the Municipal Manager, as Head of Administration, is responsible for the formation and development of an economic, effective, efficient and accountable IDP administration.; works within the performance management system of the municipality; and is responsive to the local community's needs for participation in municipal affairs (RSA 2000:34). According to this section the responsibility of the municipal manager is subject to the municipal council policy directions. The accounting officer, however, is not responsible for the legislation but is responsible for its execution. 
Generally speaking, the relationship between a municipality's political and administrative arms should not be seen as a master-servant relationship, but rather as a multi-faceted and dynamic one (Cameron, 2003:55). Municipal councils in South Africa exercise both legislative and executive roles, and the reason for this is to encourage cooperation between elected officials, executive and administration, and to allow a more responsive municipality to provide efficient service (SALGA 2014:9). In a complex environment, the politicians / councilors and officials work closely together, and uncertainty about their roles and responsibilities can lead to tensions and/or tensions within the establishment.

It remains common knowledge that councillors cause difficulties in administering their excessive intervention which ultimately negatively affects service delivery. Another issue is the cases in which management workers hold positions in political parties that misrepresent the reporting lines within local government. The municipal manager must not take the position that he / she is in charge of the municipality (excluding the executive), as this may harm the interrelationship between the politicians and the supervisor (SALGA 2014:11).

According to Svara (1999b:679), the boundaries between politicians and managers are gradually blurred and changing to include more management and administration in political matters as well as mission-definition in the management sphere. As such, the roles of politicians and managers can overlap where politicians can be involved in operational choices, while managers can be active in policy-making (Svara 2001:179). The question is how to manage the relationship between elected officials and municipal administrators in a way that ensures that the municipal service is not misused for narrow party political purposes, but remains an instrument of service delivery for the public as a whole, but under the governing party's policy direction.

Consequently, annual audit reports released by the South African Auditor General tend to point to a troubling pattern of inadequate record-keeping as one of the factors leading to disclaiming audit opinions in state institutions. State bodies are disclaimed, thus, because of a lack of supporting documents. The Auditor-General, in such instances, is not often able to communicate an opinion on many of the financial statements of state institutions, which is primarily due to insufficient records (Ngoepe \& Ngulube, 2015:1). The majority of municipalities remains in distress as a result of wide-ranging systemic challenges. Such challenges included wasteful, fruitless, irregular expenditures, serious service delivery backlogs, a breakdown in governance systems, unethical conduct and wildcat service delivery protests (Powell, O'Donovan, Ayele \& Chigwata, 2014:5-6). Although municipalities seeking disclaimer opinions face serious consequences, such as lack of public interest, loss of reputation, citizen impatience for improved service delivery, maladministration inquiries or an abrupt leadership shift without talent management. The Auditor-General thus treats disclaimer opinions as one of the two worst-case opinions - the other being an adverse opinion where auditors fundamentally disagree with the representations of financial management being established (Ngoepe \& Ngulube, 2015:1).

Bureaucratically, the organisation's existence is decided by management. It is thus a structured organizational and administrative structure designed to guarantee productivity and effectiveness (Jones and George 2009:49). It ensures that the organization fulfils expectations; it also ensures that its purpose and goals are achieved by the organization. In order to do this, an organization's managers perform certain roles and duties, including organizing, controlling, directing, coordinating and likely to lead. Managers can perform these duties effectively and efficiently if they possess certain skills that may include interpersonal skills, conceptual skills, human skills, and technical skills (Kehinde and Somoye, 2011:34). Jones and George (2009:9) described four tasks that management performs in an organization or a company. The tasks are: "to plan, organize, lead and control" (Burke, 2010). Though Karam (2011:89) writes that the basic theme of the approach to contingency is that organisations have different circumstances and ways to deal with. Management must keep the company functioning in accordance with the needs of its members and the outside powers.

\section{$>$ Political-administrative interface deflating innovative management}

Given that local government in the Republic of South Africa is on the service delivery coalface, strong leadership is required that is capable of coping with the demand and change inherent in this sphere of government. Meyer and Cloete, (2006:305) asserted that powerful, comprehensible and transformative political and executive leadership is required to steer the implementation process in the right direction to achieve organizational goals, supported and coordinated by committed administrative support services whose actions have no conflicting service delivery outcomes. Above all, following a stronger line of separation and enforcing the Municipal Finance Management Act that has prohibited councilors from engaging in contract decisions (s 117 MFMA) and has other clauses aimed at separating the council from the management.

In investigating the factors that enable Munzhedzi to thrive on corruption, (2016:2) argues that increased management autonomy for public servants leads to excessive discretion and creates opportunities for fraud and corruption as public managers are liberated from traditional budgetary control. Incompetent and unskilled people cannot deliver services effectively and consistently. Proficiency and moral principles are key to an efficient and successful public service (Areff, 2012). Service delivery is adversely affected by people driving local government without the requisite skills. Most frequently, municipalities will resort to outsourcing services, even though citizens are working to provide such services. Contracting out is placing pressure 
on the municipalities budgets. The budget for delivering services is consequently adversely affected.

The role of public servants needs to be focused on a deep understanding of the ideals of the public sector and the principles of the public sector. Public servants are required to place the collective interest on all things and all circumstances above their individual interest. Public servants should demonstrate the required conduct of public organizations: offering guidance on the basis of objective facts and evidence rather than personal preferences; acting courageously in 108 upholding the rule of law; and honouring norms and customs and their spirit in promoting change (Bourgon, 2015:14). The fundamental personal qualities of those who deliver the service become imperative and vital to being able to deliver services for a diverse customer profile. Getting the 'best talent' and new technologies is no longer proper. Public service leadership is expected to be a combination of personal qualities, strength of character, operating in a well-possible environment (Hassan, 2016:10). Furthermore, the public service needs strong managers / leaders, as their position is often more difficult than that of managers / leaders at comparable levels in the private sector. The truth is that most of the issues facing governments are complicated and need imaginative and innovative leadership.

Subsequently, municipal councils' legislative functioning is essential to maintaining sound democratic processes that promote government institutional accountability, responsible decision taking and supervision. As for the above, in reporting the 2007/08 audit results for local government, the Auditor General found that financial control in municipalities has improved dramatically in areas where opposition parties are challenging a governing party (Pressly 2009). This significant remark illustrates the value of democratic transparency as a part of good governing.

In combining governmental and administrative positions within the council, the new local regime structure does not establish optimal conditions for the council's constitutional control of the administrative and administration. That does not, however, exclude local authorities from utilizing the Supervisory System. Indeed, the study shows that numerous local authorities have embraced hampering government systems, rather than strengthening oversight. This directly applies to committee structures (de Visser, 2010).

It comes as no surprise that portfolio committees are vital to any council's functioning. The hard work is undertaken in the committees of every working democratic assembly, where the effect of decisions on neighbourhoods and citizens is also addressed in depth. The same holds true for municipalities. It is only in the smallest sphere of government where superfluous committee structures are present. We are important in all other ways in ensuring effective cooperation between councillors, local officials and the administration. Municipalities have the liberty to design their own committee schemes in terms of statute. The basis for municipal committees are articles 79 and 80 of the Municipal Structures Act. 'Section 79 committees' shall contain all or most of the Council parties and shall report to the Plenary Assembly. They are headed by a councillor who is not a part of the municipal executive. 'Section 80 commissions' also comprises all or most members of the Council who refer to the executive of the municipality. The committee is headed by an executive member (i.e. a mayoral committee or member of the executive committee) and intended to support the executive (de Visser, 2010).

The system of municipal government is wrapped among political groups and relies on party-political gatherings to make available funding, direction and transparency. The Deputy Minister for Public Governance and Cultural Relations recently commented: "Micromanaging councillors are not part of the party structures, that also has nothing to do with ensuring the councillors operate more quickly and accurately in managing tenders and dealing in workers' appointments in a limited manner. Municipal bodies shouldn't be viewed almost like political organization subcommittees (quoted in Local Government Research Centre 2009: 16). When political systems represent limited personal or factional interests, the transformative local government system is inherently counterproductive to that. Furthermore, councillors themselves are gradually opposing outside party systems of intervention. These intervention causes councillors and their neighbourhoods to wedge and councillors are wary of their own party political groups (de Visser, 2010).

Too often, regional political systems of ruling party try to take charge of municipalities remotely, in preference to giving strategic and ethical guidelines to the local caucus. Research indicates that this kind of inappropriate intervention happens mainly in staff appointments, tenders, credit management decisions and the enforcement of the Code of Conduct. Further ambiguity between the political party and the municipality is created when a senior party office-bearer is a component of the municipality workforce. The normal lines of transparency then no longer make sense, predominantly when the mayor is outranked by the member of staff. The chief of staff then simply becomes the political leader, weakening the mayor's political leadership. The municipality is then 'rewired' in a very prejudicial way. This also results in ongoing political disputes that spill over into service delivery problems. (De Visser, 50). Therefore, all moral procedures pertaining to management and innovation collapses wherein administrators operate as pons while good governance is fully compromised.

Above all, clarification is needed regarding the MSA rules on career appointments and training of employees. However, there are a variety of confusing areas of operation. The law restricts the role of the municipal council in appointments of workers to three areas. Initially, the council endorses human resource management regulations that the municipal manager will enforce like a recruitment strategy. Second, the council selects senior executives as suggested earlier. Third, they oversee the execution of their human resource policies. There are, 
however, other cases in which councillors are active in staff assignments (other than senior management) by being members of selection committees or acting as 'observers' in interviews. The MSA will make it clear that employee appointments are handled by the relevant administrators, not by councillors, just as the MFMA does with regard to tenders. The board, in effect, oversees those managers. The source of uncertainty is the role of the managers reporting to the executive manager. The council appoints them, but they are accountable to the municipality executive. The legislation is actually ambiguous where the duty and competence rests in reprimanding senior managers when they break staff codes. It is suggested that the law should make the municipal manager responsible for appointing, disciplining and dismissing the managers he or she reports to. The municipal manager must consult the council, but ultimately must be in charge of the decision (de Visser, 2010).

\section{FINDINGS}

\section{Why local authority should innovate}

Given the above obstacles to innovation, the context in which local government in South Africa finds itself makes innovation a key component of any attempt to improve the ability of individual municipalities and the local government system as a whole. Although the state and other relevant stakeholders have decided to commit considerable capital to improve local government efficiency, local government development challenges persist. Innovation remains a key element which will help build sustainable capacity in municipalities in South Africa.

Lues (2016:16) concur with the above statement as argued that innovation offers a way for municipalities to face growing budgetary pressures and satisfy new societal demands. Meeting economic and social needs in the face of capacity shortages for public service delivery, instances include the shortage of trained and qualified staff, monetary limits, and legislative scope and complexity. It will require that municipalities foster innovation centred on improving the efficacy and performance of the administration of public resources (Rivera León, Simmonds and Roman, 2012:17).

There are still significant flaws in how municipalities are regulated. A significant backdrop to these problems in municipalities is the complete absence of powersseparation within the council. It is worth researching the division of powers but there are certain important amendments which may already be rendered without amending the Constitution. In particular, political-party structures need to pursue a dynamic equilibrium between effective democratic control and intra-management (de Visser, 2010). Local sphere of government must commit ample obligatory resources to efficiently implement eligibility criteria to bearers of their offices, processes and executive administration. Conclusively, it may entail some legal amendments to demonstrate the politic and administrative partnership arms of the municipalities
However, three main drivers of public sector innovation were detected by (Rivera León, Simmonds and Roman, 2012:17) as political ambition (election mandates, pressure by politicians, leadership changes); public demand (citizens demand better and more public services at lower costs); and tightening resources (budget reductions or inadequate funding sources). Other drivers include social and cultural changes, which are normally linked to different visions of socio-economic development.

\section{CONCLUSION}

In creating a more constructive partnership between the groups and their societies, the level of local government administrative leadership needs to be seriously scrutinised and strengthened. The point would be to turn the key emphasis away from extreme legislative and executive powers in local bodies while neglecting the value of implementing and enforcing these orders. Therefore, instead of wasting resources on exploring a potential sharing of responsibilities among local authorities, it is proposed that the relevant stakeholders accept smaller structural improvements in governance of Local Councils. Most precisely, the local political and administrative leadership and the government systems surrounding them should be well aware of the devastating effects that unethical actions and political interference might sway on the running of municipalities and, thus, on the provision of services. Innovative leadership should be given space to be operational in local authorities.

\section{REFERENCES}

[1]. Amit, R., and P.J.H. Schoemaker. 1993. Strategic assets and organizational rent. Strategic Management Journal 14: 33-46.

[2]. Areff, A (2012) ANC cadre deployment 'drags down public services'. Available at: http://mg.co.za/article/2012-07-12-anc-cadredeployment [Accessed 7 July 2016]

[3]. Arpaci I, Arifoğlu A (2009). E-transformation and technological innovation in Turkey. Proceedings of the European and Mediterranean conference on information systems (EMCIS). 13-14 July, İzmir, Turkey.

[4]. Arslan A (2009). A Strategic Orientation Model for the Turkish Local eGovernments. Proceedings of 1st International conference on eGovernment and eGovernance. 12-13 March, Ankara.

[5]. Arslan, A. 2011. Innovative management practices and their impact on local e-government performance: The Turkish provincial municipalities. ResearchGate.

[6]. Bernie, L., Hafsi, T., and Deschamps, C. (2011). Innovation in the Public Sector: The Institution of Public Administration of Canada Innovation Award 1990-2011.

[7]. Bloch, C., Bugge, M., and Sliperseater, S. (2010). Measuring Innovation in the Public Sector-Key Issues and Concepts. Danish Centre for Studies in Research and Research Policy (CFA), University of Aarhus, Denmark. 
[8]. Borins, S. (2002). Leadership and Innovation in the Public Sector: Leadership and Organisation Development Journal. Volume 23(8) PP. 467-476.

[9]. Brown MM (2007). Understanding e-government benefits: an examination of leading-edge local governments. Ame. Rev. Pub. Adm., 37(2): 178-197.

[10]. Bourgon, J. (2015) Understanding the Public Leadership Environment: Preparing people to serve People in the 21st Century. Canada: Commonwealth Association for Public Administration and Management.

[11]. Burke, R.E. (2010) Essentials of management and leadership in public health. The George Washington University: Jones and Bartlett learning

[12]. Cameron, R. 2003. Politics-administration interface: the case of the City of Cape Town. International Review of Administrative Sciences, 69(3):53-65.

[13]. Canningham, P., and Karakasidou, A. (2009). Innovation in the Public Sector: Policy Brief Number 2. Manchester Institute of Innovation Research, University of Manchester.

[14]. Chen J, Liu Z, Wu N (2009). Relationships between organizational learning, innovation and performance: an empirical examination. International conference on information management, Innov Manage. Ind. Eng., 3: 488-492.

[15]. Daft, R.L., and K.E. Weick. 1984. Toward a model of organizations as interpretation systems. Academy of Management Review 9: 284-295.

[16]. DeGroot L (2005). Generating improvement from within: the role of the improvement and development agency for local government. Loc. Gov. State, 31(5): 677-682.

[17]. Demir H, Yavuz A (2009). Cadastral services in Turkey within the framework of new public management, Afr. J. Bus. Manage., 3(10): 582-590.

[18]. de Visser, J. 2010. The political-administrative interface in South African municipalities assessing the quality of local democracies. Commonwealth Journal of Local Governance

[19]. Eisenhardt, K.M. 1989. Making fast strategic decisions in high-velocity environments. Academy of Management Journal 32: 543-576.

[20]. Eisenhardt, K.M., and M.J. Zbaracki. 1992. Strategic decision making. Strategic Management Journal 13: 17-37.

[21]. Fahey, L. 1981. On strategic management decision processes. Strategic Management Journal 2: 43-60.

[22]. Hassan, M.A. (2016) Research Population. Available from: $\quad$ https://www.academia.edu 15563491/Research_Population. [Accessed: 04 August 2016]

[23]. Hartley, J. (2005). Innovation in Governance and Public Service: Past and Present: Organisation Analysis Institute of Governance and Public Management, Warwick Business School, Journal of Management Studies. Volume 31(3) PP 405-431.

[24]. Hess, M., and Adams, D. (2007). Innovation in Public Management: The role and function of community knowledge. The Public Sector Journal, Volume 12 (1) PP 1-20.
[25]. Holden SH (2006). A model for increasing innovation adoption: lessons learned from the IRS e-file program. Innovation series. IBM center for the business of government. Retrieved from: http://www.businessofgovernment.org/sites/default/fil es/HoldenRepor t2.pdf.

[26]. Jones, G.R. and George, J.M. (2009) Contemporary management Sixth edition. New York: McGrawHill/Irwin

[27]. Johnson, G. 1988. Rethinking incrementalism. Strategic Management Journal 9: 75-91.

[28]. Karam, P.N. (2011) Management Concepts and Organizational Behaviour. New Delhi: I K International Publishers

[29]. Kehinde, J.S and Somoye, R.O.C (2011) Organization Performance: The Roles and the Duties of Managers. Journal of African Macroeconomic Review Vol.1, No.1 (2011)

[30]. Larbi, G. A. (1999). The New Public Management Approach and Crises States. United Nation Research Institute for Social Development: Discussion Paper No. 112. Geneva, Switzerland.

[31]. Levitt, B., and J.G. March. 1988. Organizational learning. Annual Review of Sociology 14: 319-340.

[32]. Lichiello P (1999). Guidebook for performance measurement. Seattle, WA: turning point resources on performance management, national program office, university of Washington.1. Retrieved from: http://www.turningpointprogram.org/Pages/pdfs/perfo rm-manage/pm c-guide.pdf.

[33]. Lihua W, Zheng Q (2005). Internet Use and EGovernment Performance: A Conceptual Model, 9th Pacific-Asia Conference on Information Systems, July 7-10, Bangkok, Taiwan.

[34]. Lindblom, C.E. 1959. The science of 'muddling through'. Public Administration Review 19: 79-88.

[35]. Lindblom, C.E. 1979. Still muddling, not yet through. Public Administration Review 39: 517-526

[36]. Local Government Research Centre 2009, SA Local Government Briefing September 2009.

[37]. Lues, B. (2016), "The role of local government in using social innovation for improved service delivery: A 21st century strategy with reference to South Africa", African Journal of Public Affairs, Vol. 9/3, pp. 70-

80, https://repository.up.ac.za/bitstream/handle/2263/5 $\underline{8221}$

/Lues_Role_2016.pdf?sequence $=1 \&$ isAllowed=y (acc essed on 02 April 2019).

[38]. March, J.G. 1978. Bounded rationality, ambiguity, and the engineering of choice. Bell Journal of Economics 9: 587-608.

[39]. March, J.G. 2005. Parochialism in the evolution of a research community: The case of organization studies. Management and Organization Review 1: 5-22.

[40]. Mayer, H. (2012). Organisational Innovation Management Approaches in South Africa. Innocentrix (Pty) Ltd: Pretoria, South Africa.

[41]. Meyer, I. and Cloete, F. (2006) Policy dynamics: change, failure and success. In Cloete, F., Wissink, $\mathrm{H}$. 
and De Coning, C. (eds). 2nd edition. Improving Public Policy. Pretoria: Van Schaik Publishers.

[42]. Min Q (2009). An empirical study on the effect of information system innovation usage on performance: based on the innovation climate perspective. International conference on management science \& engineering. September 14-16, Moscow, Russia.

[43]. Moura ESP (2009). E-government implementation and total quality management adoption: an empirical study in the Portuguese municipalities. 13th IRSPM (The International Research Society for Public Management) conference proceedings. International center for business and politics.

[44]. Munzhedzi, P.H., (2016) South African public sector procurement and corruption: Inseparable twins? Journal of Transport and Supply Chain Management. Available from: http://www.google.co.za/url?sa=t\&rct=j\&q=\&esrc=s $\&$ source $=$ web $\& c d=25 \&$ ved $=0$ ahUKE wjJjf3n9OjOAhVHBsAKHevnAgA4FBAWCEUwB A\&url=http\%3A\%2F\%2Fwww.jtscm.co.za\%2Findex. php\%2Fjtscm\%2Farticle\%2Fview\%2F197\%2F407\&u sg=AFQjCNHcwusgx kObIgFGtGPMVs68zEdnA\&sig2=iweFJ0h8z2Y5lmg47_wrLg. [Accessed 30 August 2016]

[45]. Ngoepe, M. \& Ngulube, P. 2015. A framework to embed records management into the auditing process in the public sector in South Africa, Information Development: 1-14. Available at: www.sagepub.co.uk/journalsPermissions.nav. Downloaded from idv.sagepu.com on 17 February 2016.

[46]. Padovani E, Yetan A, Orell RL (2009). Municipal performance measurement in practice: which factors matter? IPMN conference, Seoul National University, Seoul, June 23-24, p. 200.

[47]. Powell, D.M., O'Donovan, M., Ayele, Z. \& Chigwata, T. 2014. Operation clean audit: Why it failed and what can be learned. Cape Town: MLGI

[48]. Powers LC (2009). A framework for evaluating the effectiveness of performance measurement systems. Real World Systems Research Series 2009:1. Retrieved from: http://ssrn.com/abstract=1371158.

[49]. Pressly, D. 2009, Criticism fosters greater efficiency, Business Report, 15 July in de Visser, J. 2010. The political-administrative interface in South African municipalities assessing the quality of local democracies. Commonwealth Journal of Local Governance

[50]. Republic of South Africa. 2000. Local Government Municipal Systems Act 32 of 2000. Pretoria: Government Printers.

[51]. Republic of South Africa. 1998. Local Government Municipal Structures Act 117 of 1998. Pretoria: Government Printers.

[52]. Republic of South African Local Government Association (SALGA). 2014. Guideline Document on the Roles and Responsibilities of Councillors, Political Structures and Officials.
[53]. Rivenbark WC, Kelly JM (2003). Management innovation in smaller municipal government. State Local Gov. Rev., 35(3): 196-205.

[54]. Rivera León, L., P. Simmonds and L. Roman (2012), Trends and Challenges in Public Sector Innovation in Europe, European Commission, http://ec.europa.eu/DocsRoom/documen ts/ 13181/attachments/1/translations

[55]. Shipalana, M.L (2019). Innovative Management in the South African Public Service. A Case for the Limpopo Department of Health. Leadership and Management, Doctoral Thesis, Nelson Mandela University.

[56]. Sørensen, E., and Torfing, J. (2012): "Introduction: Collaborative Innovation in the Public Sector". The Innovation Journal: The Public Sector Innovation Journal, Volume. 17(1), P. 1-14.

[57]. Svara, JH. 1999. Complementarity of politics and administration as a legitimate alternative to the dichotomy model. Administration \& Society, 30(6):676-705.

[58]. Svara, JH. 2001. The Myth of the Dichotomy: Complementarity of Politics and Administration in the Past and Future of Public Administration. Public Administration Review, 61(2):176-183.

[59]. Svara JH (2008). A Study of the Scope and Dynamics of Innovation in City Government: A Literature Review and Exploration of SinoAmerican Differences. Paper presented at Annual Conference of American Society for Public Administration, March 10. Retrieved from: urbaninnovation.asu.edu/academicnetwork/pdf/Svara_ASPA2008.doc.

[60]. Vinzant JC, Vinzant DH (1996). Strategic management and total quality management: challenges and choices. Pub. Adm. Q., 20(2): 201.

[61]. Walker RM, Damanpour F, Devece CA (2010). Management innovation and organizational performance: the mediating effect of performance management. J. Public Adm. Res. Theory, 21(2): 367386. 